AWEJ for Translation \& Literary Studies, Volume 5, Number 1. February 2021 DOI: http://dx.doi.org/10.24093/awejtls/vol5no1.19

Pp.262 -278

\title{
Pip's Ego Oscillations in Charles Dickens's Great Expectations
}

\author{
Bechir Saoudi \\ English Department, College of Science and Humanities, Hotat Bani Tamim, Prince Sattam Bin \\ AbdulAziz University, Al-Kharj, Riyadh, Kingdom of Saudi Arabia \\ English Department, ISEAH, Kef, Jendouba University, Tunisia \\ Correspondent Author: ctat.ctat@yahoo.com \\ Lama Fahad Al-Eid \\ English Department, College of Science and Humanities, Hotat Bani Tamim, Prince Sattam Bin \\ AbdulAziz University, Al-Kharj, Riyadh, Kingdom of Saudi Arabia \\ Noura Mohammed Al-Break \\ English Department, College of Science and Humanities, Hotat Bani Tamim, Prince Sattam Bin \\ AbdulAziz University, Al-Kharj, Riyadh, Kingdom of Saudi Arabia

\section{Rahaf Saad Al-Samih} \\ English Department, College of Science and Humanities, Hotat Bani Tamim, Prince Sattam Bin \\ AbdulAziz University, Al-Kharj, Riyadh, Kingdom of Saudi Arabia \\ Tarfah Abdullah Al-Hammad \\ English Department, College of Science and Humanities, Hotat Bani Tamim, Prince Sattam Bin \\ AbdulAziz University, Al-Kharj, Riyadh, Kingdom of Saudi Arabia
}

Received: $12 / 10 / 2020$

Accepted: 2/2/2021

Published: $2 / 24 / 2021$

\begin{abstract}
This research project studies Pip's ego fluctuations in Charles Dickens's Great Expectations. Freud's division of the human psyche into id, ego and superego is appropriate for the analysis of the rise and fall of the hero in his pursuit to attain gentlemanhood. Four main questions have been addressed: First, what makes up Pip's id? Second, what are the main components of his superego? Third, does Pip's ego succeed or fail in striking a balance between his id and superego? In what ways does it fail? And fourth, how does Pip's ego eventually succeed in striking a balance between his id and superego? The study finds out that Pip's id is demonstrated through his fascination with high-class lifestyle and relinquishment of common life. It shows that his superego is constructed from the hurdles that prevent him from pursuing gentlemanhood, namely past common life restraints and present high class deficiencies. It also demonstrates how Pip's faulty ego comes as a result of his frustration at high class lifestyles and resentment of his old common life. The study eventually reveals that two important factors contribute to the success of Pip's ego: His reconciliation with the past and appreciation of the present in order to have more realistic expectations of the future. Keywords: Charles Dickens, ego, Freud, Great Expectations, id, oscillations, superego Cite as: Saoudi, B., Al-Eid, L. F., Al-Break, N. M., Al-Samih, R.S., Al-Samih, R. S., \& Al-Hammad, T. A. (2021). Bechir Saoudi. Arab World English Journal for Translation \& Literary Studies 5 (1) 262 -278. DOI: http://dx.doi.org/10.24093/awejtls/vol5no1.19
\end{abstract}




\section{Introduction}

Charles Dickens (1812-1870) was one of the most important and influential British writers of the Victorian Era. He was also an editor, social commentator and journalist. He wrote such cherished classics as Hard Times, A Christmas Carol, David Copperfield, Oliver Twist, A Tale of Two Cities, Nicholas Nickleby and Great Expectations. He heavily influenced such predominant writers as Kipling, Conrad, Joyce, and Eliot.

Great Expectations is "one of its author's greatest critical and popular successes" ("Great," 2020, para. 1). It has been extensively admired as the Dickens's greatest literary achievement. It was first published in book form in 1861. It is a serialized account of the psychological development of its hero, Pip, "from an innocent, unsophisticated orphan to a pseudo-aristocrat and snob" and beyond (Allingham, 1861, para. 2). It also addresses such issues as ambition, selfimprovement, social class, crime, guilt, innocence, sophistication and human worth. Great Expectations is popular both with readers and literary critics (Schlicke, 1999). It has been studied from numerous perspectives including psychoanalytic criticism. Yet within this type of criticism, Freud's three divisions of the human psyche, the id, ego and superego, have not been fully investigated in relation to the central character. This is a great opportunity for the researchers to fill the gap and explore and experiment with a very important tenet of psychoanalytic literary criticism.

\section{Thesis Statement}

This research project aims at studying Pip's psyche using Freud's notions of id, ego and superego in relation to his journey to attain gentlemanhood. It is important to investigate the various facets of a personality created by one of the most distinguished authors through a psychoanalytic critical lens.

\section{Key Research Questions}

The study seeks to answer important questions posed in Psychoanalytic literary criticism through the personality of Pip in Great Expectations. What represents Pip's id? What are the main components of his superego? Does Pip's ego succeed or fail in striking a balance between his id and superego? In what ways does the ego fail? How does it succeed in putting things right for the protagonist?

\section{Significance and Purpose of the Study}

This literary study is very beneficial in that it fills a gap in knowledge that has not fully been dealt with previously, namely the application of Freudian criticism to Great Expectations in the pursuit of getting to grips with the complexity of relationships between a person's id, ego and superego. It aims at scrutinizing the work in order to find out about the oscillations of the ego between the id and the superego and assess the outcome thereof. The study is also particularly critical in that it deals with literature, one of the three main disciplines studied at Prince Sattam bin AbdulAziz University, the other two being linguistics and translation. In fact, most research projects have so 
far dealt with education sciences and language teaching issues at the expense of the other disciplines. This project will encourage more researchers to opt for literary projects so as to address the disproportion. The article also makes a significant contribution to the existing literature on psychoanalytic approaches to the novel in terms of the focus and depth of its analysis.

\section{Literature Review}

Great Expectations has stimulated various reactions from different critics using a range of critical approaches. What the researchers are interested in in this project is the psychoanalytical theory whose progress has had an enormous impact on literary criticism. One of the ways researchers could study Great Expectations from a psychoanalytic perspective is to explore the relationship between the author and his work, concentrating on how Dickens's own life influenced the novel. Another way is to examine the readers' response to the novel and how they may psychologically identify with the characters. A third way focuses on the construction of a character's identity in relation to society. Other critics may be interested in the analysis of characters from a psychoanalytic angle. The researchers' endeavor falls within this last realm.

Numerous studies have read the novel from psychoanalytic standpoints. One reason is that "because it enters the abyss of Pip's inner self" (Bloom, 2010, p. 1). Dessner's 1976 "Great Expectations: 'The Ghost of a Man's Own Father'" investigates the complex relationship between Dickens as a dreamer and Pip as his dream. In "Repetition, Repression, and Return: Great Expectations and the Study of Plot", Brooks (1980) reads Great Expectations with Freud's Beyond the Pleasure Principle, using Freud's concept of repetition to explore the novel.

Lehman's 2004 "Repressions in Great Expectations" studies the ways "repressed feelings, thoughts, and actions" in the novel "offer greater depth of meaning to the plot and its characters" (para. 1). Ingham's 2008 "The Superego, Narcissism and Great Expectations" focuses on the link between the superego and narcissism and how the latter may be seen as a product of the former. In "Feeling for the Future: The Crisis of Anticipation in Great Expectations", Tyler investigates the "delineation of Pip's future-oriented psychology" and describes "Pip's feelings of uncertainty about the future" (2011, p. 1). In "Desiring Estella in Great Expectations: Understanding Pip's Fantasy", Reynolds focuses on the love relationship between Pip and Estella and the way they "have resolved some of their maladaptive psychology" (2015, para 8). Within psychoanalytical criticism, Freud's basic notions of the id, ego and superego have not been fully investigated in relation to the hero of Great Expectations. Hence, it is essential to fill the gap and explore Pip's psyche using basic Freudian terminology in an innovative way.

\section{Theoretical Framework}

The present study is concerned with discussing three fundamental parts of personality or psyche in Freudian psychoanalytical literary criticism. In The Ego and the Id (1927), Freud conceives of the human mind as made up of three components, the id, the ego, and the superego.

Arab World English Journal for Translation \& Literary Studies 
The id is the center of a person's instincts. It is predominantly sexual and violent in nature and is determined by the pleasure principle (Snyder and Lopez, 2007, p. 117). The superego represents the common ethical principles and social rules that define what is right and what is wrong, what is acceptable and what is frowned upon. It is driven by the reality principle, the aptitude of the mind to evaluate the reality of the outside world, and to react to it (Freud, Strachey, $\&$ Richards, 1984, p. 278). It counterbalances the pleasure principle that controls the id.

In Freud's theory of the psyche in general, the ego is to be understood as the moderator or arbitrator responsible for striking a balance in mind between the id and the superego. If the ego fails to manage or cope with the id-superego struggle, or release repressed desires one way or another, it develops into a faulty ego, as opposed to a healthy ego if it succeeds. In the current study, the notions of id, superego, faulty ego and healthy ego shall be respectively applied to the four main parts of the project, as shown in the research design section below.

\section{Research Design}

The study of Pip's ego oscillations in his pursuit of gentlemanhood in Great Expectations is divided into four main parts. The first part concerns the study of the ways Pip's id is revealed through his yearning to become a gentleman. Pip's id is demonstrated by his infatuation with the Satis house lifestyle, his cover-ups on its flaws, his abandonment of his own common life, and his thirst for education.

The second part studies Pip's superego as displayed through the factors that stand in the way of his pursuit of gentlemanhood: namely past common life limitations and present high class defects. Common life limitations are demonstrated through a carrot-and-stick strategy from Pip's neighborhood, whereas high-class repulsion is revealed through the Satis House aversion and gentlemanly life repellents.

The third part discusses the failings of Pip's ego in reaching a compromise between his id and superego, resulting in a faulty ego. Pip's disappointment in the repulsion from the Satis House and discomfiture at certain gentlemanly aspects leads to his distress. The situation is aggravated by his frustration at Joe and Biddy, the villagers, and the reemergence of Magwitch in his life. The fourth part deals with the successes of the ego in learning from its failures in order to ultimately reach a certain level of satisfaction in achieving genuine gentlemanliness. Two vital components lead to the triumph of the ego. First, Pip learns how to build great relationships in the present instead of relying on unrealistic expectations of the future. Second, Pip succeeds in reuniting with his past, making it part of his present as well.

\section{Part I- The Id}

Pip's id is expressed through manifestations of his pressing need for becoming a gentleman. It is brought to the fore through his interactions with the Satis family, reactions to his past common life, concealment of the drawbacks of a rich life, and his earnest plea for education. 


\section{The Satis House Trigger}

Pip's intense desire to rise above his social station and become a gentleman is first unraveled in chapter 9 when Mrs. Joe announces that Pip is going to "play" for Miss Havisham (Dickens, 1861, p.92). It meant a lot for Pip even though his journey towards gentlemanhood would merely start with him acting as Miss Havisham's mere walking stick (chap. 14). Ever since he visited the Satis House, he developed a longing to be part of the upper-class life he had a small taste of (chap. 15). He continues to visit the Satis house for eight months to learn more about the new life. In chapter 17, Pip goes for a walk with Biddy to whom he openly confesses his desire to change and become a gentleman. He decides to embrace wealthy society values and hold them up as ideal against his own common life background.

\section{Common Life Renouncement}

Pip's desire to become a gentleman is related in his mind to getting rid of his old common lifestyle. In chapter 10, he clearly expresses his desire to be uncommon. He starts despising the common worker as less worthy than the well-mannered gentleman leading a well-off, restful way of life (chap. 14), basing his thoughts on society's discriminatory ideas of "gentleman" and "common". Pip classifies the convict as less than common even though he does not know either about the kind of crimes he committed, or their circumstances (chap. 39).

\section{Cover-up on High Life Downsides}

Pip's yearning to achieve gentlemanliness leads him down the way of dishonesty and deceit in his attempts to cover up on the newly discovered shortcomings of high-class life. He actually lies in order to vindicate an ideal portrayal of the gentleman-like life he appears to be bent on pursuing until the end no matter what happens in the process. Pip tries to become uncommon and climb the social ladder by being crooked, as Joe puts it, and lying about his experiences (chap. 9). He lies to the impatient Mrs. Joe and Mr. Pumblechook in a wondrous manner, inventing stories about Miss Havisham reclining on velvet couches and dogs feeding on veal, glorifying the wealthy Satis House lifestyle (chap. 9).

\section{Craving for Education}

Pip's insistence on becoming uncommon and a gentleman is further emphasized by his determination to get educated immediately after his great expectations were announced. Pip is dissatisfied with the education he gets from the "ridiculous old woman", Mrs. Wopsle (chap. 7, p. 75) and is motivated by the prospect of refining himself into becoming uncommon (chap. 10). That is why he asks Biddy to help him learn the basics (chap. 10). She agrees and gives him some books to start with. She even teaches him a ditty about a man who goes to London and leads an extravagant life (chap. 15). A further incentive for Pip to insist on a gentlemanly education was Estella's being sent abroad to be educated as a lady (chap. 15). But Pip is not contented with only educating himself, he is also concerned with raising the level of his acquaintances. When he realizes that Joe is illiterate (chap. 7), he, in turn, starts to teach him everything he has learned regardless of how much Joe is actually capable of taking in (chap. 15).

Arab World English Journal for Translation \& Literary Studies 
Pip's id, particularly his strong desire to become a gentleman, is illustrated in his fascination with the Satis House high class lifestyle, his cover-ups on its deficiencies, his relinquishment of his own common life, and his hankering after education. This paves the way for the forces that would stand in the way of achieving his dream, the superego.

\section{Part II- The Superego}

In Freudian theory, the human mind is structured around an id-superego relationship that represents the struggle between the pleasure principle and the reality principle. The id is driven by the former principle whereas the superego is driven by the latter (Freud, 1927). In Pip's case, the superego is mainly constructed from past common life restraints and present high-class repulsion.

\section{High Class Repulsion}

People representative of high class life are inclined towards belittling Pip and rejecting his plea to become one of them. Besides, their lifestyle, Pip discovers, is full of deficiencies, which might tune down his resolve to become a gentleman altogether. Ironically, the higher society Pip would like to rise to is represented by the cruel environment at the Satis House.

\section{The Satis House Repugnance}

Pip's first taste of high-class life was bitter. The Manor House, where the hostile Miss Havisham and the aggressive Estella live, is depicted as a gloomy place devoid of any form of life or feelings. "The cold wind seemed to blow colder there, than outside the gate" (chap. 8, p. 116). Miss Havisham, who is always strangely in the dark, seems to have stopped living since the day her lover jilted her many years before. Her relationship with her relatives, Georgiana, Sarah Pocket, Cousin Raymond, and Camilla, is even harsher than her relationship with Pip (chap. 11). It is based on money and power rather than mutual respect as is Pip's relationship with Joe at the forge (chap. 11). In fact, their visits to Miss Havisham is built on satisfying their insatiable greed for her money after she dies. Miss Havisham knows their intention very well as she often refers to herself as a corpse laid out as a meal for her hungry relatives to feast on (chap. 11). They visit her once a year on her birthday which turns out to be her supposed wedding day as well, the day she stopped all the clocks at home. Ever since that day, the wedding food and cake have been left untouched by anyone, exception made of rats, beetles and spiders that creep at liberty through the house. The abandoned meal and cake are a blunt reflection of the absence of love and human friendship that meals usually connote (chap. 13). Thus, while pursuing his dream of becoming a gentleman, Pip finds himself heading towards a life of death, decay, and empty relationships where he merely plays the role of Miss Havisham's walking stick.

Apart from the serious deficiencies of high-class life, Pip is denied access to its sphere because of his disqualification and ineligibility from a high-class viewpoint. Miss Havisham suddenly turns into a happy and contented creature when Estella scorns Pip for his coarse hands and thick boots (chap. 8). As a result, Pip loses his self-esteem, thinking that there is really something wrong with him, seeing Estella always ahead of him (chap. 8). Furthermore, Estella 
rewards Pip with a kiss not for his love but for his violent behavior against Herbert Pocket (chap. 11). Estella even intervenes in the choice of Pip's own friends, especially Joe and Biddy: "What was fit company for you once, would be quite unfit company for you now," she tells him (Chap. 29, p. 419). And even though Pip decides to stay away from both friends (chap. 29) in order to please Estella and Miss Havisham, the latter makes a decisive move in the way of demolishing Pip's expectations to become a gentleman: She buys Pip's indenture as a blacksmith from Joe for twenty five guineas (chap. 13).

\section{Gentlemanly Life Repellents}

Setting the Manor House lifestyle shortcomings aside, Pip's practice of "gentlemanly" life involves a number of other inconveniences that can subdue his dreams. Matthew Pocket's definition of a gentleman, as stated by his son Herbert is dispiriting for Pip: "[No] man who was not a true gentleman at heart, ever was [...] a true gentleman in manner" (chap. 22, p. 290). Besides, unlike Pip who refuses Biddy's love, Herbert's gentlemanhood does not prevent him from loving a common woman, Clara, even though Herbert's mother is totally opposed to his marrying below station (chap. 30). Also the disparity between Wemmick's private and public lives in London seems incomprehensible for Pip.

\section{Common Life Restraints}

Pip's past life environment is among the factors that stand in the way of his desire to become a gentleman. Strategies of his old life acquaintances to hold him back from proceeding with his resolve to join the rich people club oscillate between reward and punishment.

\section{The Carrot}

As soon as Pip's great expectations are announced, his old life suddenly becomes appealing. When Pip decides to become uncommon, Joe reassures him that he is already an uncommon scholar (chap. 9). His sister gets assaulted, suffers some brain damage, and her "temper [is] greatly improved, and she [becomes] patient" (chap. 16, p. 261). With her new attitude towards Pip, he starts calling her "my sister" instead of Mrs. Joe Gargery (chap. 16, p. 263). Biddy is employed to look after her, and becomes "a blessing to the household" (chap. 16, p. 261).

In chapter 27, Joe visits Pip in London and asks him to leave his pretentious lifestyle, come back to the forge and his natural old life, and sit down and talk to the real Joe like old times. In order to remind him of his past generosity, Joe uses the word "wittles" to refer to the food Pip stole in order to feed the convict (chap. 27, p. 395). He succeeds in bringing to the fore the conflict between Pip's new gentlemanly life and his supposedly better old common life at the forge (chap. 27). Pip answers Joe's call in chapter 35 and realizes that, as Joe anticipated, the situation at the forge is indeed a better setting for an honest, unpretentious relationship between friends. They feel much more comfortable in the coziness of home, with Joe smoking his pipe by the fire. That was the carrot style, but after promises come threats. 


\section{The Stick}

When Pip insists on his dream to become a gentleman and uses lies to convince others of his desire, Joe informs him that "[if] you can't get to be oncommon through going straight, you'll never get to do it through going crooked" (chap. 9, p. 150). After Miss Havisham bought Pip's indenture from Joe, Mr. Pumblechook insists that Pip be bound by law at the Town Hall so that he cannot escape the type of life and job they projected for him (chap. 13).

Pip's common past is going to scarily haunt him almost until the end as he tries to climb the social ladder. In chapter 10, he is reminded of his illegitimate past by a stranger in the pub. Pip's assistance of the convict at the beginning of the novel continues to disturb him as he tries to become educated and far distanced from it (chap. 16). In chapter 28, he surprisingly shares a carriage with two convicts who sit behind him. In Chapter 39, the convict himself visits Pip and the latter treats him with disdain before recognizing him as the convict he, as a child, helped at the graveyard. The convict proves to be very generous and compassionate towards Pip: "Look'ee here, Pip. I'm your second father" (chap. 39, p. 316). Violence and crime in general keep recurring in Pip's life as when in chapter 15 he witnesses a fight between Orlick and Joe.

Pip's superego is constructed from the factors that stand in the way of his pursuit of gentlemanhood: past common life restraints and present high class norms. Common life limitations are demonstrated through a carrot-and-stick strategy, whereas high class repulsion is revealed through the Satis House repugnance and gentlemanly life repellents.

Now, will Pip's ego be able to negotiate a deal between his id and superego? The answer is two-fold: no and yes. He first fails before he can learn from his faults and end up embracing success in achieving genuine gentlemanhood. The next section deals with Pip's ego's failures.

\section{Part III- Faulty Ego}

This part of the article explores Pip's ego as he observes his great expectations starting to crumble, accompanied with the recurring feelings of guilt and shame when answers to all the ambiguities of the novel finally start to unravel. By the end of chapter 39, Pip appears to be achieving very little in life. His life soon starts to disassemble with neither a good honest living nor a good loving wife, finding himself unemployed and Estella married to his bitter enemy. He realizes that he has actually been proceeding towards what he was trying to flee as he fails to achieve any of his expectations. In chapter 57, we find him in the worst of his states, destabilized by the burns he sustains at the Satis House, his fight with Orlick, and the trauma related to Estella's marriage.

One of the reasons behind Pip's ending up with a faulty ego is his acting against his own nature. Wemmick maintains that society forces us to act against our nature, demeaning those who stand in the way (chap. 37). There are very few moments in the novel when we find him happy. He often feels sad not only because of his conditions but also because of the peculiar way he perceives them (chap. 41). He feels unhappy through thick and thin, through his apprenticeship at 
the forge, for instance, and equally unhappy even as his great expectations are announced to him (chap. 41). Many characters in the novel, like Joe, Biddy, Magwitch and Wemmick, seem to lead a shoddier life but seem much happier than him (chap. 41).

Pip's faulty ego results from two major factors: disillusionment with high class lifestyles and frustration at his old common life antagonism.

\section{High Lifestyle Disillusionment}

The Satis House Distress

Pip's frustration with his ideal of gentlemanly life starts at the Satis House where he first gets a taste of a high class lifestyle. His experience of higher society proves to be acrimonious from day one when he walks home from the Satis House ashamed of, and embarrassed by, his supposedly low life (chap. 8). Besides, early in chapter 11, he feels sickened by the rotten food and cake and surprised at the lifelessness of the stopped clocks at Miss Havisham's. He is equally surprised at the strange characters of Miss Havisham's relatives: the "vicious," "dry, brown, corrugated" Sarah Pocket, the "grave" Georgiana, and the old melodramatic Camilla (chap. 11, p. 183). Estella tells Pip that these people are jealous of him and hate him because they believe Miss Havisham is his benefactress (chap. 33). Pip is of course unhappy with the way Miss Havisham deceived him into thinking that she was his benefactress. His prospects to become a gentleman had already been damaged by her sponsorship of his indenture as a blacksmith (chap. 12) even though the news pleased everyone except him (chap. 13). Pip's acquaintance with Miss Havisham symbolically leads to his burning himself badly and putting his life at risk while trying to extinguish the fire at her house.

Pip feels unnatural with the way he reacts to these people's bizarre manners. Compeyson, the violent criminal who jilted Miss Havisham on her wedding day, is considered an ideal gentleman by high society (chap. 42). He is surprised at the violent life of these people as he runs into a young gentleman who dares him to fight. He then feels guilty for hitting him against his nature (chap. 11). Estella's insults of Pip even make him feel ashamed of the environment in which he has been raised and even of his own relatives as he "wished Joe had been rather more genteelly brought up" (chap. 8, p. 130).

\section{Gentlemanly Life Discomfiture}

Apart from the Satis House negative influence on Pip's prospects to become a gentleman, other high life factors also play a role in his astonishment and frustration at his life as a gentleman in the city. He soon discovers that London, the ideal setting of his great expectations and bright future, is an "ugly, crooked, narrow and dirty" place (chap. 20, p. 286). He has to pay visits to Jaggers whose office is located in a macabre "Little Britain" with a chair made of material like that of a coffin (chap. 20, p. 286). Wemmick accompanies him to his residence at Bernard's Inn, and it turns out to be a decaying place that is fallen into disrepair and worse than Pip's own rural poverty at the forge (chap. 21). Pip also witnesses a chaotic scene over a meal at the Pockets' (chap. 23). He 
loathes city people's obsession with titles. The useless lazy Mrs. Pocket, for instance, spends her whole day reading about titles and ancestry (chap. 23). Drummle, the dispirited, gloomy, insulting and irritating aristocrat is respected, revered and taken as a model for being high class (chap.s 26 and 44).

Pip is also dissatisfied with his own extravagant wealthy life in London and feels guilty for leading his only true friend, Herbert, and himself into a prodigal lifestyle they would not ultimately be able to afford (chap. 34). "We spent as much money as we could," says Pip, "... We were always more or less miserable... our case was in the last aspect a common one" (chap. 34, p. 487). Pip's choice of lifestyle estranges him from his own nature and from his friends (chap. 34). He soon goes through financial difficulties, runs a fever for almost a month and, during the same period, creditors keep demanding repayment of his due debts.

Pip makes it clear that he is not proud of his state of mind and lifestyle as a gentleman in London (chap. 34). The hollowness he feels with being a gentleman is confirmed by his joining the disreputable worthless Finches of the Grove club whose members meet only to argue and get drunk (chap. 34). He stops being tutored by Mr. Pocket and does not adhere to any of the jobs he starts (chap. 39).

Even though Pip becomes rich and educated, he still cannot see himself as a true noble gentleman (chap. 39). On the contrary, he feels he has become less inclined towards generous acts than when he was in the past as a young boy with the convict at the graveyard (chap. 39).

Pip's disillusionment with high class lifestyles is revealed through his distress at the repulsion from the Satis House and discomfiture at certain gentlemanly aspects. Pip is also frustrated at his old common life antagonism.

\section{Old Common Life Antagonism}

While pursuing his dream of becoming a gentleman, Pip finds himself being held back and repressed, not only by high-class people, but also by his old hometown acquaintances. Ever since he visited Miss Havisham's, he has developed a feeling of shame towards his upbringing in a lower class family (chap. 8). The embarrassment affects his respect and love for his best friend, Joe, to whom he confesses his concern about being a commoner (chap. 9). Yet, he starts his journey towards becoming uncommon by first being dishonest, or "crooked", as Joe puts it (chap. 9, p. 125). He finds himself compelled to invent imaginary stories to convince his people of the superiority of high-class life (chap. 9).

The first real setback to his attempt to climb the social ladder comes through Miss Havisham's sponsorship of his indenture to be a blacksmith at Joe's forge. People at Joe's house enjoy the news and celebrate the event. However, Pip articulates his misery as follows: "I was truly wretched, and had a strong conviction on me that I should never like Joe's trade. I had liked it once, but once was not now" (chap. 13, p. 187). He is ashamed of both his home and of his trade, no 
matter how honest it might be (chap. 14). As he refuses his current situation, he begins to feel isolated and spends a restless evening with Joe and Biddy despite the dramatic change in his fortune (chap. 18).

\section{The Joe and Biddy Displeasure}

Pip feels that Joe and Biddy are among the first people to try and hold him back from achieving his dream. He looks down on Joe as common and low class, but attempts to raise him to a higher level by asking Biddy to educate him. Biddy declines immediately informing him that Joe, unlike him, is in no need for altering his current social level (chap. 19). When he finally leaves for London, he still feels torn between his old life and new prospects. In the carriage, he contemplates turning around to spend more time with Joe and Biddy (chap. 19).

Pip's past will continue to disturb him even after he embarks on his new life as a gentleman in London and pays occasional visits to his old village. When Pip is informed of Joe's intention to come visit him in London, he does not look "with pleasure" on the news (chap. 27, p. 386). He simply gives him the cold shoulder and it continues for years. But he later regrets it because he realizes that Joe was in fact his real benefactor who never asked for anything in return (chap. 52, p. 748). Pip's relationship with Joe and Biddy crumbles down as he becomes more and more hostile and pretentious as in chapter 39. Pip promises Biddy that he will be back in the village soon but Biddy honestly alludes to the opposite. Pip feels offended even though he knows well that she is right (chap. 35). He refrains from visiting Biddy and Joe for a long time before becoming conscious that he was in fact once again wronging them (chap. 39). His conscience disturbs him as a result of his ongoing disregard of both (chap. 34).

\section{Villagers' Reprisal}

Joe and Biddy are not the only acquaintances that seem to be pulling Pip back from his resolve to become a gentleman. Other members of his community also play their roles in the same line. While Pip is proudly enjoying a pleasant walk back in his home town, he is disturbed and made fun of by the Trabb boy who emulates the arrogant way Pip walks, shouting out, "Don't know yah!" to bystanders. Pip feels he has become a mockery (chap. 30, p. 436). On another visit to the village, an innkeeper tells Pip a distorted version of his own story and how he would ignore Pumblechook, the man who had been his benefactor (chap. 52)! Pumblechook himself rejoices in Pip's misfortune, believing that Pip had failed to show him any gratitude for having been his initial "true" benefactor (chap. 58, p. 847). In fact, the whole village starts to treat him with indifference after being so gentle with him at the beginning of his great expectations (chap. 58). That is not the end yet; another main figure from Pip's past unexpectedly reemerges in his life, choking off his dream. Pip's feeling of frustration aggravates as the convict astonishingly turns out to be his real benefactor and the one who made a gentleman out of him (chap. 39).

Arab World English Journal for Translation \& Literary Studies 


\section{Magwitch, the Last Straw}

Pip feels horrified and devastated when he learns that the real benefactor behind his great expectations is no other man than the same convict who was running away from justice at the beginning of the novel. "I've made a gentleman out of you," the man exclaims (chap. 39, p. 569). The money which set Pip on the way towards great expectations is no other than that of a criminal! He has been leading a profligate life profiting by the toil of a lawbreaker from the lowest of classes, no matter how kind to him he can be! It means there is no secret plan by Miss Havisham to make Pip's life happy or prosperous (chap. 39)! Pip sits by the fire contemplating his disgusting wretched position, being associated with the lowest of the low. He cannot indeed believe his eyes before he asks Jaggers to confirm the news (chap. 40). Magwitch has indeed once again turned Pip's life upside down as he did years back in the churchyard. Pip's pride, however, prevents him from taking any more of a criminal's money (chap. 41). And in any case, Pip feels he has not grown into the type of gentleman that Magwitch had anticipated (chap. 50).

Pip's disillusionment with high class lifestyles, revealed through his distress at the repulsion from the Satis House and discomfiture at certain gentlemanly aspects, is aggravated by his frustration at his old common life antagonism: the Joe and Biddy displeasure, the villagers' reprisal, and the reemergence of Magwitch that was the last straw that broke Pip's back. Pip's faulty ego cannot be in a worse situation. But how does Pip eventually succeed in finding a way for his id through all of those superego repressions?

\section{Part IV- Healthy Ego}

The journey of Pip's ego towards achieving his dream of becoming a gentleman finally comes to a happy ending. Two important factors contributed to the success: First, Pip reconciles with his past making it a part of his life, and then learns, through his rise and fall, and push and pull between his id and superego, how to find happiness in the present, and what it takes to have more realistic expectations of the future. He realizes that he can never live his life to the full without improving and cherishing relationships and friendships from his past and present.

\section{Beginning of a Dream: Great Expectations}

The announcement of the first of Pip's "great expectations" through a job given him "to play" for Miss Havisham mark a happy much longed-for turning point in the young boy's life (chap. 7, p. 92). It proclaims the beginning of his transition from the humble inadequate life with Joe and his wife at the forge to the company of high-class society. "This boy's fortune," says Mrs. Joe introducing his great expectations, "may be made by his going to Miss Havisham's" (chap. 7, p. 90). Then much to Pip's pleasure, the second of his great expectations is announced by lawyer Jaggers who says that Pip has been granted a large amount of money to be "brought up a gentleman" (chap. 18, p. 245). He buys new clothes and moves to London within a week. He is given lessons about life in the city and spends a lot of time reading (chap. 39). 


\section{Advantage of Nightmare}

Then it was necessary for Pip to go through unexpected misfortunes in order to start seeing the truth about his false expectations to become a fake gentleman (chap. 53). Hardships allow Pip to be transformed into an actual gentleman who discards social value judgments and values honest relationships in order to start living a fuller life (chap.s 55 and 58). He embarks on a new definition of himself and of others, his own reevaluation, not society's labeling, of individuals. He used to judge himself in a punitive manner because of the supposedly criminal and violent surroundings that kept haunting him. Now he becomes conscious that convicts can be kind, and blacksmiths loyal, while high-class ladies may be the offspring of lawbreakers, and gentlemen villains (chap. 48). And above all, the convict, his merciful benefactor, turns out to be the father of his beloved Estella. He has made a great achievement, though unintentionally, by giving him a very uncommon and high-class lady to love (chap. 50).

\section{The Awakening: Great Relationships}

Setting aside the process of his "great expectations", Pip is now contemplating the worthier true personalities of Joe and Magwitch and others, and how having great relationships with the people who matter to him can heal his wounds (chap. 52 and 53). Furthermore, from Biddy's unexpected marriage to Joe, Pip learns that one should never indulge the hope of pursuing any hollow expectations whatsoever (chap. 58). Thus Pip becomes more generous and kind to the supposedly low and common (chap. 58). After all, Magwitch has sacrificed a lot, including his own security, in order to promote Pip into a gentleman (chap. 42).

Even though the bighearted Wemmick regrets the loss of Magwitch's fortune to the crown, that does not seem to trouble Pip in the least. He decides not to live off the money of others any more, substantiating the extent of his healthy transformation from pursuing the material selfish "great expectations" towards a quest for value-based altruist great relationships (chap. 54). He becomes an honest and loyal hard-working partner at his friend Herbert's firm and succeeds in paying off his debts on his own (chap. 58).

\section{High Class Relationships}

Pip realizes that the "lap of luxury" does not necessarily lie in material gain. It could be articulated through sincere friendships (chap. 22). Pip finds Matthew Pocket a sincere tutor, so he, in turn, feels serious in learning from him (chap. 24). At Bernard's Inn, Pip lives for five years with Herbert, Matthew Pocket's cheerful son, who becomes one of his best friends. Pip adores Herbert's honesty and uprightness (chap. 22). He finds sharing city life with him very attractive. That is why he asks Jaggers to allow him to continue living with Herbert (chap. 24). Pip accompanies Herbert to go and enjoy seeing Wopsle in a laugh-out-loud comical performance of Hamlet (chap. 31). In the evening, they invite Wopsle home for dinner to listen to him rant and rave about his role in the play (chap. 31). Pip also grows fascinated with Wemmick's slogan "Office is one thing, private life is another" (Chap. 25, p. 369). He enjoys his entertaining hospitality and humane compassion 
at home, far distanced from the office in which Wemmick seemed to Pip to be like a machine (chap. 25).

Close friends learn to go through thick and thin together. With the help of Wemmick, Pip anonymously grants Herbert one hundred pounds a year and helps him get a job. Wemmick describes Pip's gestures to assist Herbert as "devilish good" (chap. 37, p. 526). Again in chapter 55 Pip and Miss Havisham work together to secretly secure a job for Herbert. In his turn, Herbert takes care of Pip's burns in chapter 50 and unintentionally returns Pip's favors by offering him a job and a place to stay when he is in need (chap. 55).

At the beginning, Pip considers the simple act of seeing Miss Havisham on a regular basis a milestone on the way towards his promising gentlemanly future (chap. 12). He takes recommendations from the Satis House for an ideal, especially when he decides to ignore Joe and Biddy based on the way he thinks Miss Havisham and Estella want him to act (chap. 30). Yet, Miss Havisham's later transformation affects Pip deeply. In chapter 49, he finds her very lonely, looking almost fearful of him, without any trace of the former arrogance or pride. She even offers to help Pip assist his friend Herbert financially (chap. 49). She asks Pip for forgiveness which he immediately grants, telling her that he himself needs to be forgiven by others, especially Joe and Biddy.

\section{"Common" Relationships}

Pip, now a genuine gentleman, learns how to reconcile with his past and cherish old time relationships with Joe, Biddy, other villagers and Magwitch.

Joe and Biddy. After the announcement of his great expectations, Pip starts to treat people differently, including Joe and Biddy (chap. 19). Fortunately, Joe pardons Pip for everything he did in order to disassociate himself from them. After the death of Pip's sister, he finds out that she, in turn, had indeed asked Joe to pardon him (chap. 35). The proof of Joe's forgiveness comes to the fore as he stands beside Pip when he slips into a long coma, eventually helping him to heal (chap. 57). Pip is again assisted, as in his childhood, by the exceptional support of Joe (chap. 57). Furthermore, as Pip starts to recover from his illness, he learns that Joe has repaid all his debts, substantiating his true friendship, leaving it to Pip to prove his (chap. 57). Pip then transforms into a much different person from the proud snob who would ignore Joe and Biddy because people would talk (chap. 56). After all, it was Biddy who agreed to help Pip with books and education so that he can be eligible for gentlemanhood (chap. 10). Yet, Pip met her generosity with vanity and arrogance going as far as pretending to correct his teacher Biddy's grammar (chap. 19). Eventually, Pip asks Joe and Biddy for forgiveness which they grant with pleasure much to his delight. Even more, they give birth to a little boy whom they name Pip.

Villagers. There is no record of an ameliorated relationship between Pip and his neighbors after his awakening. Yet, before that, when Pip first comes into fortune, people start treating him 
differently (chap. 19). He walks around town, delighting in the appreciative looks of his neighbors (chap. 30). Pumblechook treats him like a king, and Pip enjoys it from the pretentious idiot he used to loathe (chap. 19). Even the marshes, the symbol of Pip's common past, are now appreciated by Pip who finds them, through his rose-tinted glasses, beautiful all of a sudden (chap. 19).

Magwitch. Magwitch, the convict, has changed Pip considerably. In chapter 39, Pip becomes aware of Magwitch's gratitude to him for the kind act of providing him with desperately needed food back in the marshes. "You acted noble, my boy," says Magwitch, "Noble Pip!" (chap. 39, p. 563). Then Magwitch puts his life in harm's way to come back inside the country in order to meet the gentleman he conceived. Furthermore, Pip starts sympathizing with Magwitch when he realizes that he has actually been a victim of social prejudice and labels (chap. 42). People labeled him as a criminal who would spend most of his life in prison, and so it was (chap. 42). Yet, he mostly stole out of desperate need of food and shelter. Even though Compeyson, a gentleman in the eyes of society, was the mastermind behind Magwitch's crimes, he gets a lesser sentence than the socially labeled common Magwitch (chap. 42).

For all of those reasons Pip tries his utmost to protect Magwitch and ensure he does not get arrested and executed (chap. 40). He disguises him as a wealthy farmer and hides him (chap. 40). However, he gets arrested, but Pip remains on his side. At the court, he assists him out of the chambers much to the disapproval of the audience. Pip is cured of his pride and is no longer afraid of what people might think of his acquaintances. His hate of Magwitch has turned into a love that is worth being shamelessly expressed in public (chap. 56).

Pip's ego fluctuations between his id and superego close on a high note when he eventually achieves his dream of becoming a genuine gentleman. Two important factors contributed to the success of the ego. First, Pip learns, through the push and pull between his id and superego, how to find happiness in building great relationships in the present, not in relying on unrealistic expectations of the future. Second, Pip succeeds in reconciling with his past, making it a part of his present as well. He recognizes that improving and cherishing relationships and friendships, past and present, is the cornerstone of happiness and reconciliation between the pleasure and reality principles.

\section{Conclusion}

Studying the fluctuations of Pip's ego between his id and superego in Charles Dickens's Great Expectations has proven effective through the use of the three Freudian divisions of the psyche. Four main questions have been addressed: 1) What represents Pip's id? 2) What are the main components of his superego? 3) Does Pip's ego succeed or fail in striking a balance between his id and superego? In what ways does it fail? And 4) How does Pip's ego eventually succeed in putting things right for the hero? The study has managed to answer its key research questions and reached the following results: First, Pip's id, particularly his strong desire to become a gentleman, is illustrated in his fascination with the Satis House high-class lifestyle, his cover-ups on its 
deficiencies, his relinquishment of his own common life, and his hankering after education. Second, Pip's superego is constructed from the factors that stand in the way of his pursuit of gentlemanhood: past common life restraints and present high class shortcomings. Common life limitations are demonstrated through a carrot-and-stick strategy, whereas high class repulsion is revealed through the Satis House repugnance and gentlemanly life repellents. Third, Pip's disillusionment with high-class lifestyles, revealed through his distress at the repulsion from the Satis House and discomfiture at certain gentlemanly aspects, is aggravated by his frustration at his old common life antagonism: the Joe and Biddy displeasure, the villagers' reprisal, and the reemergence of Magwitch in Pip's life. Fourth, the journey of Pip's ego towards achieving his dream of becoming a gentleman finally comes to a happy ending. Two important factors contributed to the success: Pip reconciles with his past making it a part of his life, and learns, through the push and pull between his id and superego, how to find happiness in the present, and what it takes to have more realistic expectations of the future. He realizes that he can never live his life more fully without improving and cherishing relationships and friendships from his past and present.

Applying Freudian psychoanalytic criticism to the study of Great Expectations has proven to be a fruitful exploration of literature. This study can be taken as a model to study other aspects of the novel, particularly love between Pip and Estella and the theme of security. The approach can also be applied to other literary works that lend themselves to examination through psychoanalytic criticism.

\section{About the Authors:}

Bechir Saoudi got his Ph.D. in English Literature and Cultural Studies from the University of Manouba, Tunisia. He is currently an Assistant Professor of English literature at the English Department of the College of Science and Humanities, Hotat Bani Tamim, Prince Sattam bin Abdulaziz University, Al-Kharj, Saudi Arabia. His research interests are in the literary and cultural studies domain. ORCiD: https://orcid.org/ 0000-0001-5593-6891

The rest of the authors are graduate students of English Language and Literature at the College of Science and Humanities, Hotat Bani Tamim, Prince Sattam bin Abdulaziz University, Al-Kharj, Saudi Arabia.

Bechir Saoudi, ORCiD: https://orcid.org/ 0000-0001-5593-6891

Lama Fahad Al-Eid, ORCiD: https://orcid.org/ 0000-0002-1092-400X

Noura Mohammed Al-Break, ORCiD: https://orcid.org/0000-0003-4337-0602

Rahaf Saad Al-Samih, ORCiD: https://orcid.org/ 0000-0001-9866-0426

Tarfah Abdullah Al-Hammad, ORCiD: https://orcid.org/ 0000-0001-7080-7393 
AWEJ for Translation \& Literary Studies Volume, 5 Number 1. February 2021

Pip's Ego Oscillations in Charles Dickens's

Saoudi, Al-Eid, Al-Break, Al-Samih \& Al-Hammad

\section{References}

Allingham, P. V. (1861). An Introduction to Charles Dickens's Great Expectations. In All the Year Round. Ontario: Lakehead University. Retrieved from http://www.victorianweb.org/authors/dickens/ge/pva12.html

Bloom, H. (Ed.). (2010). Bloom's Modern Critical Interpretations: Great Expectations. Chelsea House Publications.

Dessner, L. J. (1976). Great Expectations: "The Ghost of a Man's Own Father". PMLA, 91(3), 436-449.

Dickens, Charles. (1861). Great Expectations. London: Chapman and Hall. https://etc.usf.edu/lit2go/140/great-expectations/

Freud, S. (1927). The Ego and the Id (J. Riviere, Trans.). Hogarth Press. (Original work published 1923)

Freud, S., Strachey, J., \& Richards, A. (1984). On Metapsychology: The Theory of Psychoanalysis : 'Beyond the Pleasure Principle, ' The Ego and the Id' and Other Works. Harmondsworth: Penguin.

Great Expectations. (2020). In Encyclopadia Britannica Online. Retrieved from https://www.britannica.com/topic/Great-Expectations-novel-by-Dickens

Ingham, G. (2007). The Superego, Narcissism and Great Expectations. The International Journal of Psychoanalysis, 88(3), 753-768.

Lehman, D. (2004). Repressions in 'Great Expectations'. Retrieved from https://danielmlehman.wordpress.com/2004/04/20/repressions-in-great-expectations/

Reynolds, C. W. (2015). Desiring Estella in Great Expectations: Understanding Pip's Fantasy. Retrieved from

http://www.victorianweb.org/authors/dickens/ge/reynolds.html

Schlicke, P. (1999). Oxford Reader's Companion to Dickens. Oxford: OUP.

Snyder, C. R., \& Lopez, S. J. (2007). Positive Psychology. Sage Publications Inc.

Tyler, D. (2011). "Feeling for the Future: The Crisis of Anticipation in Great Expectations", 19: Interdisciplinary Studies in the Long Nineteenth

Century 0(14). Retrieved from https://doi.org/10.16995/ntn.607

Arab World English Journal for Translation \& Literary Studies

ISSN: 2550-1542 | www.awej-tls.org 